\title{
ARISTOTLE ON POETS: A CRITICAL EVALUATION OF RICHARD JANKO'S EDITION OF THE FRAGMENTS
}

\author{
Malcolm Heath
}

\begin{abstract}
This paper provides a critical examination of Richard Janko's edition of the fragments of Aristotle On Poets (Janko 2011). Section 1 discusses passages preserved in late ancient texts which Janko assigns to On Poets. Section 2 identifies problems in the evidence preserved in the Philodemus papyri. Section 3 assesses indirect evidence for Aristotle's theory of katharsis, and considers two contested points in Aristotle's discussion of katharsis in Politics 8: the meaning of mousike, and the nature of his response to the challenge posed by Plato in Republic 10.
\end{abstract}

Richard Janko's edition of Philodemus On Poems book $1^{1}$ combined exceptional philological expertise and ingenuity with a seemingly superhuman patience and attention to detail. Indeed, his editorial achievement far outshone in intellectual stature the mediocrity of Philodemus and his opponents. He has now edited the remains of books 3-4. ${ }^{2}$ These, though less extensive than those of book 1 , hold out a prospect of more rewarding content: in book 4 ('a treasure', as Janko calls it: viii) Philodemus apparently begins an engagement with Aristotle's lost dialogue On Poets which continues into book 5. For this reason, Janko supplements his edition of Philodemus with an edition of the fragments of On Poets, supported by a substantial introduction and commentary. An earlier version of this collection of fragments, without a Greek text or any elaborate scholarly apparatus, was appended many years ago to Janko's translation of Aristotle's Poetics. ${ }^{3}$ It did not then receive close scrutiny from reviewers, and there is a risk that this new version, similarly appended to other material by which it may be overshadowed, will not be reviewed in detail. An edition which 'more than quadruples the number of fragments' (400) certainly merits careful scrutiny. Yet few scholars command the full range of expertise needed for a comprehensive assessment of material drawn from late ancient sources as well as from Philodemus. Since I am neither a papyrologist nor an expert on Philodemus, my own contribution must draw primarily on my knowledge of Aristotle and of late ancient intellectual culture. Accordingly, the first section of this review discusses in some detail the identification and interpretation of some of the passages preserved in late ancient texts which Janko assigns to On Poets; the treatment of evidence preserved in the Philodemus papyri in Section 2 will necessarily be briefer. Section 3 will give separate consideration to a variety of sources of evidence for Aristotle's theory of katharsis, including (most importantly) evidence provided by Aristotle himself.

In what follows, I follow Janko's numeration to identify texts which he has printed as fragments of On Poets. But to avoid prejudging the question of whether the identification of a given text as a fragment of On Poets is correct, I shall use the prefix ' $\mathrm{J}$ '

Janko 2000.

Janko 2011. In what follows, references to this book will be given by page number alone.

Janko 1987. 
(instead of the standard abbreviation ' $\mathrm{F}^{\prime}$ ). ${ }^{4}$ Similarly, since the interpretation of fragments is sometimes an issue, I provide my own translations, giving Janko's rendering for comparison where divergences are potentially significant.

\section{The evidence of late antiquity}

Janko separates testimonia from fragments. The latter include, for example, excerpts from Politics 8, though these are not fragments of On Poets in any normal sense. Janko explains that he classes texts that attest to the existence of On Poets as testimonia, while his fragments include texts which report or provide other indirect evidence for the content of On Poets, even if they do not transmit Aristotle's own words (403). ${ }^{5}$ Combining the two kinds of evidence is a defensible policy, though using the term 'fragments' (rather than, for example, 'sources' $)^{6}$ for both is potentially misleading. It is, at any rate, important to maintain a conceptual, if not a terminological, distinction, since different kinds of source place different constraints on editorial practice. It is legitimate to try to restore the probable wording of the original text by emendation if one is editing a fragment in the strict sense, but not if one is editing a later author's paraphrase. Janko is not consistently alert to this distinction. ${ }^{7}$ Consider, for example, J36c, from John the Deacon's commentary on pseudo-Hermogenes On Method (150.7-9 Rabe): ${ }^{8}$

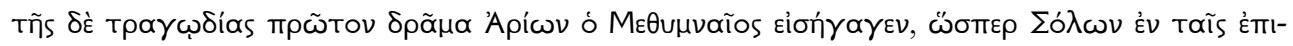

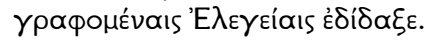

Arion of Methymna introduced the first tragic drama, as Solon taught in his work with the title Elegies.

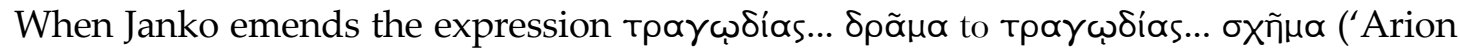
of Methymna introduced the first form of tragedy'), what has he emended? Substituting the more Aristotelian expression would be justified in a reconstruction of Aristotle's original text. But such a reconstruction presupposes that John has given us a fragment in the strict sense (transmitting Aristotle's words, though in a corrupt form), rather than in Janko's extended sense (transmitting Aristotle's thought in what may be a free paraphrase). Since we have no reason to believe that this passage is a fragment in the strict sense, eliminating from the text of John the Deacon a periphrasis for 'tragedy' attested elsewhere in late ancient scholarship ${ }^{9}$ is illegitimate.

An even more fundamental question is whether we have reason to believe that J36c is an Aristotelian fragment in any sense. It is not a named citation. The source of the information is explicitly identified in John's text as Solon, not Aristotle. Perhaps the

\footnotetext{
4 A concordance of Janko's numeration with those of Rose 1886, Gigon 1987 and Laurenti 1987 can be found in Appendix 2 below.

5 Janko distinguishes doubtful fragments with an asterisk; he includes one spurious fragment, marked with a dagger, but also provides a list of other exclusions (403-7).

6 See e.g. Fortenbaugh et al. 1992: 4-9.

7 This point was made long ago by reviewers of Janko 1984: Barnes 1985: 104-5; Schenkeveld 1986: 214; Fortenbaugh 1987: 157-9; Bremer 1988: 168.

8 Rabe 1908a published extracts from Vat. gr. 2228. Janko designates this as 'cod. unicus', which is not strictly correct: Rabe 1908 b.

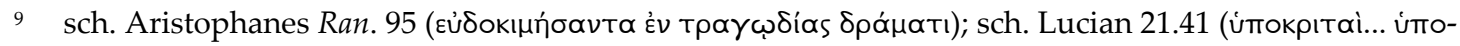

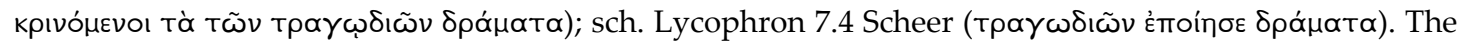
fact that this reading commits John to what is, to our eyes, a very implausible claim is not in itself evidence that he did not write it.
} 
statement about Arion attributed to Solon was transmitted by Aristotle: but do we have any reason to believe that? Aristotle held that tragedy arose out of dithyramb (Poet. 4, 1449a9-11), and Proclus reports (J36a) that Aristotle claimed that Arion originated dithyramb. But there is a difference between originating dithyramb and introducing tragedy. So Proclus' report cannot safely be regarded as a variant of John's report that Arion introduced tragedy, and gives no positive support to the conjecture that Solon's claim that he did so was transmitted by Aristotle. Nor does that conjecture gain any support from the fact John has mentioned Aristotle only a few lines earlier. Here is the sentence in a slightly extended context (150.1-10 Rabe): ${ }^{10}$

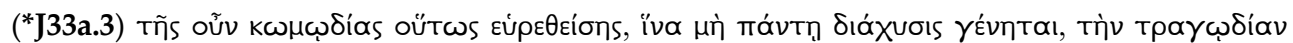

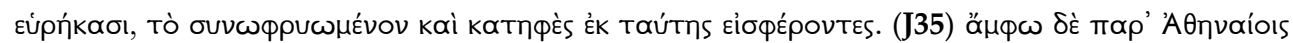

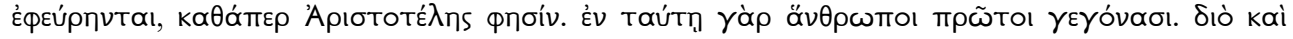

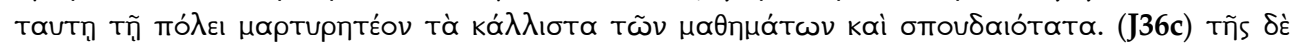

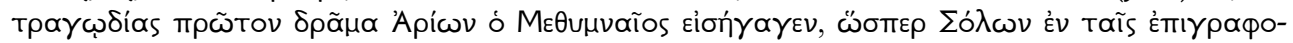

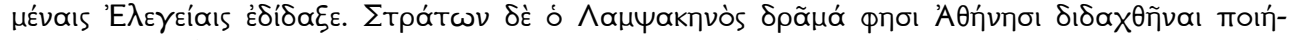

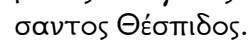

(*J33a.3) Once comedy had been discovered in this way, to avoid there being uninterrupted merriment they discovered tragedy, introducing frowning and downcast eyes by means of it. (J35) Both were invented in Athens, as Aristotle says. For it is there that humans first came into existence. That is why one should attribute to this city the finest and most serious of studies. (J36c) Arion of Methymna introduced the first tragic drama, as Solon taught in his work with the title Elegies. But Strato of Lampsacus says that drama was first produced at Athens, when Thespis composed it.

Does Aristotle's authority extend beyond the sentence in which he is named? Not if my translation is correct: Aristotle is unlikely to have said that humans originated in Athens, since in his eternal world the question of human origins does not arise. ${ }^{11}$ But Janko's translation of the crucial phrase is different: 'it is in Athens that human beings have become preeminent.' This, however, neglects the specific tradition that lies behind John's text. The Attic origin of humans goes back to Plato (Mnx. 237d-8b); Aelius Aristides took it up in the Panathenaicus $(25,33)$, and in the same work he also mentioned the Athenian origin of weaponry (43). These two ideas were combined by Themistius, who says that the claim that weaponry first appeared in Attica is reasonable, given the Attic origin of mankind (Or. 27, 337a). This passage in Themistius comes immediately before a statement about the origins of tragedy (J34). It is therefore not likely to be a coincidence that John's supporting argument for the Athenian invention of tragedy reproduces the structure of Themistius' supporting argument for the Athenian invention of weaponry. It follows that John's citation of Solon's statement about Arion (J36c) is separated from the statement attributed to Aristotle by name (J35) by a statement that John (or, rather, his late ancient source) has modelled on something said by Themistius in the context of, but not about, the origin of drama. This intervening

\footnotetext{
10 See Appendix 1 below for a more extended presentation of the passage in John from which *J33a+J35+J36c are extracted (149.6-150.10 Rabe), alongside the partial parallel in the commentary on $\mathrm{On}$ Method attributed to Gregory of Corinth (RG 7.1328.8-9.1 Walz). The two commentators shared a common late antique source, from which they independently selected and adapted material (Rabe 1908a: 130-2). Note that *J33b (from Gregory), which abbreviates the source of *J33a.2-3, includes a reference to festivals which is a displaced summary of the source of *J33a.1.

11 See DC 1.3, 270b16-25; Met. 12.8, 1074a38-b14; Mete. 1.3, 339b16-30; 1.14. Discussion in (e.g.) Sedley 2007: 119-20; Cambiano 2002; Verlinsky 2006.
} 
statement is not Aristotelian. There is therefore no reason to regard J36c, or any part of J35 beyond the named citation, as a fragment of Aristotle. ${ }^{12}$

Themistius demands further attention. He is prominent in Janko's collection of fragments of On Poets, furnishing substantial additions to the fragments to be found in Rose or Gigon. Janko maintains that Themistius was exceptional, for someone of his late date, in having had direct access to Aristotle On Poets: 'in the fourth century AD the De poetis became the preserve of learned philosophers, since so far as we know only Iamblichus and Themistius read it' (392). I shall have more to say about Iamblichus in §3. For the present, it is enough to note that Janko offers no evidence for his direct knowledge of On Poets: he simply refers us to J55, in which Iamblichus does not name Aristotle, let alone On Poets, and where Janko's commentary speaks more cautiously of 'dependence on Aristotle, direct or indirect' (520). In the case of Themistius, the belief that he had direct knowledge of On Poets is apparently grounded on, and in turn provides support to, the belief that he is the source of otherwise unattested fragments of Aristotle. This reasoning need not be viciously circular: the more reason we have to believe that Themistius mediates fragments of On Poets that are not attested in any earlier text, the more plausible it is that he had direct access to On Poets; and that, in turn, will lend support to the identification of fragments in Themistius which might otherwise have seemed doubtful. But the risk of circularity is there, and we need to satisfy ourselves that the case for identifying fragments of On Poets in Themistius is a strong one.

We may start with J34 (Themistius Or. 27.337a-b). This follows the passage mentioned above, on which the second part of J35 is modelled, and contains Themistius' statement about the origin of tragedy. According to Themistius, tragedy, though perfected in Athens, was invented in Sicyon, just as comedy originated in Sicily and was enhanced in Athens. A first point to observe is that Janko's hypothesis creates an apparent contradiction in Aristotle. If J34, J35 and J36c are all, as Janko claims, fragments of On Poets, then Aristotle said that tragedy was invented in Sicyon, invented in Athens, and first introduced by Arion. Janko proposes a complicated way to reconcile this seemingly extravagant variety of claims about the origins of tragedy (365-71). But the reconciliation is unnecessary: the fact that Aristotle's name appears in only one of these three 'fragments' (indeed, only in the first sentence of J35, according to which Aristotle said that tragedy was invented in Athens) suggests that the problem is an artefact of Janko's mistaken attributions.

It might be objected that J34, at least, is marked as Aristotelian by its reference to the Sicilian comic dramatists 'Epicharmus and Phormus'. Janko comments: 'the presence

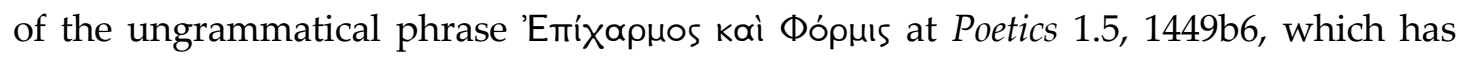
often been deemed an interpolation from a parallel passage in the De poetis, strongly supports the assignation of J34 to the De poetis' (366). But what exactly is it that

\footnotetext{
12 The subsequent reference to Strato (the transmitted text has Draco: Janko adopts Patzer's conjecture, plausibly) suggests the possibility that it was Strato who mentioned the Solon fragment and dissented from it. But there are no strong grounds for asserting this: John's source is likely to have combined snippets from many different sources. This possibility, and the source's knowledge of late antique literature, are illustrated by the fact that the named reference to Aristotle (J35), which is followed by the

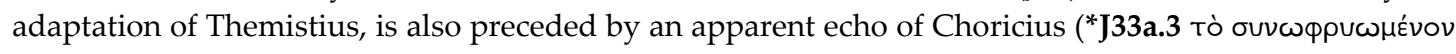

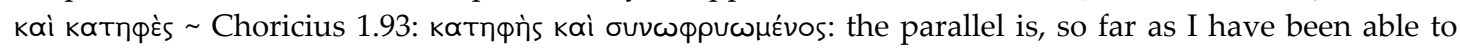
determine, unique).
} 
provides this support? The fact that the phrase is not an authentic part of the text of the Poetics (i.e. is interpolated) is not in itself evidence that it is an authentic part of the text of On Poets. Nor is the fact that the phrase in Poetics 'has often been deemed' an interpolation from On Poets evidence that the phrase is a fragment of On Poets: the crucial question is whether it has rightly been so deemed -in other words, we need evidence that the phrase is a fragment of On Poets. Combining an unsupported conjecture about the source of J34 with an unsupported conjecture about the source of the interpolation in Poet. 5, $1449 \mathrm{~b} 6$ would yield only the flimsiest of self-supporting structures. Let us therefore consider the matter in a larger context. It is beyond reasonable doubt that the phrase in the Poetics is an interpolation. ${ }^{13}$ From this, it does not follow that the pairing of Epicharmus and Phormis must have reached Themistius from some other Aristotelian work. They are also paired in Suda E2766 and $\Phi 609$, which supply additional information about them; the source is identified in E2766 as Lycon. So it is possible that Themistius took the names either from Lycon or from some link in a doxographic tradition leading from Lycon to the Suda. The interpolation in the Poetics might derive from the same tradition. Alternatively, since the interpolation in the Poetics is apparently not an early one, ${ }^{14}$ it might derive from Themistius himself. The existence of such alternative possibilities means that we have no reason to suppose that Epicharmus and Phormis made a joint appearance in any Aristotelian text. Therefore Janko's argument for identifying J34 as a fragment of $\mathrm{On}$ Poets fails.

There is another, much longer extract from Themistius that Janko includes among the fragments of On Poets $(O r .26,316 a-9 a=J 38+J 43 a)$. The context is a defence of innovation. Themistius first mentions (J38) various examples of human progress: statuary, ship-building, diet ${ }^{15}$ and housing, painting and music, and the development of tragedy from its purely choral beginnings through the inventions of Thespis and Aeschylus to Sophocles and Euripides. Aristotle's support is invoked by name in the case of tragedy. Themistius then proceeds (J43a) to trace at much greater length the development of philosophy from Thales and the Presocratics through Socrates and Plato to Aristotle. Since Aristotle's On Poets is unlikely to have included a history of philosophy culminating in Aristotle himself, Janko prudently truncates the purported Aristotelian fragment before Themistius reaches Aristotle's contribution to philosophy. But why should we attribute any of this history of philosophy to Aristotle? It can hardly be claimed that Themistius, who Janko rightly describes as a 'learned philosopher' (392), would have been incapable of composing such an account himself. But there is evidence that he did, at least, have some help in conceiving the idea: Diogenes Laertius has a similar, though briefer, comparison of the histories of tragedy and philosophy $(3.56=\mathrm{J} 42)$. This parallel makes it probable that such a comparison was present in a source common to Diogenes and Themistius. In Diogenes the history of philosophy does not extend beyond Plato, and Janko acknowledges (505) that Themistius (or, less economically, an

\footnotetext{
13 See Tarán in Tarán and Gutas 2012: 245. Janko himself is non-committal (365 n.2; cf. 1987: 80, where the phrase is retained), which makes his appeal to the support of the (in his view, possibly mistaken) view that the phrase is interpolated in Poet. 5, 1449 b6 even stranger.

14 The names were not in the Greek ancestor of the Syriac-Arabic tradition: see Gutas in Tarán and Gutas 2012: 334-6.

15 Themistius here mentions balanophagy, which also appears in *J33a.1, from John the Deacon (see n.10 above). That may give further support to the inference that the common source of John and Gregory made use of Themistius. There is no reference to balanophagy in extant Aristotle.
} 
intermediate source) has elaborated the material taken over from the common source at least to the extent of extending the history of philosophy. But it would not be safe to assume that this is the only respect in which Themistius modified the common source.

Even if we knew that Aristotle was the common source of the passages in Diogenes (J42) and Themistius (J38+J43a), therefore, we would not know how far Themistius was adapting and expanding, rather than simply paraphrasing, Aristotle. But we do not know that Aristotle was the common source of Diogenes and Themistius. We do not even have reason to suppose that the common source made any extensive use of Aristotle. Themistius names Aristotle as an authority only in support of the claim that tragedy developed by a series of incremental innovations. This reference to Aristotle could have been introduced by the common source into a body of material that was not derived from Aristotle; or Themistius himself could have introduced it into a body of material derived from the common source. ${ }^{16}$ Indeed, the reference to Aristotle, so far from authenticating the Aristotelian provenance of other material in the context, counts against it: if all or most of J38+J43a was derived from Aristotle, why should he be named just at this one point? Since the full extent of Themistius' adaptation of the common source is not known, we must recognise the possibility that he was able to supply from his own wide reading the examples that precede the history of tragedy in J38, or which follow it in J43a. The idea that an accomplished and scholarly orator who had occasion to compose a defence of innovation must have taken it over slavishly from a single source is not realistic.

Janko does, however, have a further argument for connecting Themistius' history of philosophy with Aristotle. The end of the tribute to Plato runs as follows (J43a.6):

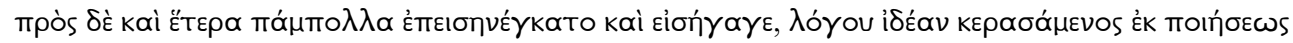

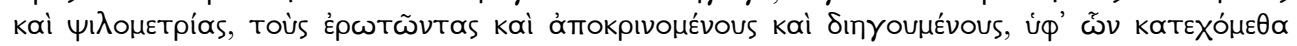

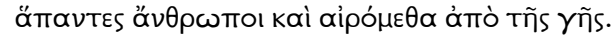

In addition, he made very many other innovations, and introduced (blending a style [idea] of discourse [logos] from poetry and bare prose) people asking questions and answering them and telling stories, by whom all we humans are enthralled and raised above the earth.
\end{abstract}

There is an apparent parallel in Diogenes, who reports Aristotle as saying that the style (idea) of Plato's discourses (logoi) is between poetry and prose' (

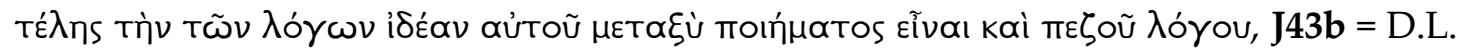
3.37). Since Diogenes makes this point in a completely different context, the parallel does not license us to assume that the point about Plato's style was made in the common source which we have inferred for Themistius Or. 26, 316a-9d (J38+J43a) and Diogenes 3.56 (J42). Here, too, we must recognise that Themistius could himself have made this addition to material that he had adapted from the common source. Moreover, this case provides no evidence to support Janko's claim that Themistius had direct access to On Poets, since the parallel in Diogenes is evidence that by Themistius' time the point was preserved in indirect tradition.

More importantly, there are issues of interpretation. Janko's text and translation differ from those given above in two important respects: he translates logos as 'dia-

16 Laurenti 1987 includes this as his F4c (i.e. only the last 5 of the 23 lines of Janko's J38, and none of the 59 lines of his J43a). If this citation of Aristotle was inserted by Themistius, I am not confident that he would have scrupulously checked his memory of what Aristotle said against the original text. Janko defends Themistius' report of Aristotle against various suspicions that have been raised against it (370-1): nevertheless, reports are not always reliable (see n.19 below). 


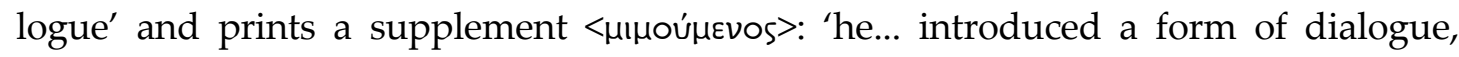
blending it from poetry and bare prose, <imitating > people asking questions and answering them and telling stories' (443). ${ }^{17}$ These two decisions nudge the passage in the Aristotelian direction that he thinks it should take. But there are two problems. First, the supplement is not adequately motivated unless we have independent reason to believe that Themistius is making an Aristotelian point. Secondly, the word which Themistius uses elsewhere when he wishes to refer specifically to dialogue is not logos, but dialogos. In this passage, Themistius does acknowledge the dialogical character of Plato's discourse; but he does by means of an allusion to a standard definition of dialogue in terms of question and answer (D.L. 3.48; Alb. Intr.1), combined with a reminder that Plato also includes narrative elements (such as the myths). ${ }^{18}$ As we shall see, however, Themistius' concern in this passage is not with the dialogue form as such.

In his discussion of Themistius (J43a) Janko maintains that 'the paraphrase of this same idea' in Diogenes (J43b) 'demonstrates that Themistius depends on the De poetis' (508). What exactly is this idea? Janko is confident that the idea in both passages relates to the framework of generic classification which Aristotle constructs in Poetics 1, with Socratic dialogues as a form of mimesis in prose (Poet. 1, 1447b9-13). But whatever it is that Themistius is referring to, he explicitly regards it as one of Plato's many innovations. A multiply attested fragment explicitly attributed to On Poets records that Aristotle awarded priority in the composition of dialogues, not to Plato, but to Alexamenus of Teos (J44a, c, e). ${ }^{19}$ So if Themistius' concern here is with the mimetic dialogue form as such, the assignment of priority to Plato contradicts Aristotle's attested views on the origins of mimetic dialogue in prose. But it is questionable whether that is what Themistius is concerned with. First, in an author of the fourth century AD, it is hard not to see stylistic analysis in the phrase 'blending an idea', which echoes the technical terminology of contemporary rhetorical theory. ${ }^{20}$ Stylistic comment would not be out of place: the legitimacy of the poetic elements in Plato's prose style had been a matter of debate for centuries..$^{21}$ Since idea is used elsewhere in connection with the invention of

\footnotetext{
17 For ease of comparison, I have given an adapted form of my own translation. In Janko's own words: 'he... introduced a form of dialogue by mixing it from poetry and prose, <representing> people asking questions and answering them and narrating.'

18 I think this more likely than a reference to the dramatic/diegematic classification of dialogues (Plut. QC 711b-c; D.L. 3.50).

19 Elsewhere Janko highlights Aristotle's award of priority to Alexamenus, claiming that it 'brings to light' one of two 'contradictions in Plato's argument' (that is, in his 'provocative condemnation of poetry as $\mu$ '́ $\left.\mu \eta \sigma \iota \varsigma^{\prime}\right)$ : 'that he cannot have the credit for inventing the Socratic... dialogue' (319). If we had to reconstruct Plato's argument from this passage of Janko, we would have to infer that Plato claimed to have invented the Socratic dialogue, and that this claim played an important role in his condemnation of poetry. Otherwise, how would Aristotle's denial that Plato invented Socratic dialogue have any bearing on Plato's argument? (Even then, strictly speaking, denying Plato's priority would bring to light a false premise in Plato's argument, not a contradiction.) Similarly, when Janko speaks of 'Plato's rejection of poetry in general' (320), we would have to infer that this rejection embraced all kinds of poetrywhich is false: Plato explicitly licenses hymns to the gods and encomia of good men (Rep. 10, 607a). When assessing evidence for lost texts, and drawing inferences from that evidence, we need to take a realistic view of the reliability of second-hand reports.

20 See Hermog. Id. 215.9-11, 305.6 Rabe; Longinus F49.108-9 Patillon-Brisson = 212.4-6 Spengel-Hammer.

21 See e.g. Dionysius of Halicarnassus' Letter to Pompeius, where he defends his earlier criticisms of Plato; Caecilius' criticisms of Plato evoke a sharp response in Longinus On Sublimity. For a survey see Walsdorff 1927.
} 
the dialogue form as such (Athen. 11, 505c), this argument is not in itself decisive. But, secondly, Themistius' interest is in the effect that Plato has on his readers: 'all we

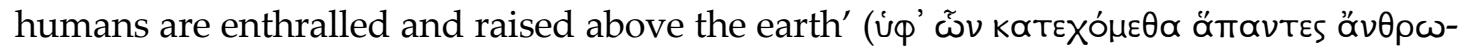

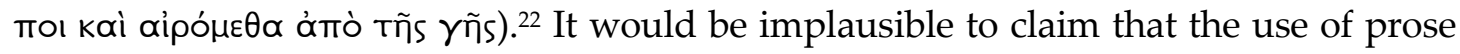
mimesis as such (which was not, in any case, distinctively Platonic) was the source of that elevating effect: what enthrals and elevates is Plato's distinctive style.

Themistius' interest in J43a is therefore in the innovative and elevating admixture of poetic elements in Plato's prose style, rather than in generic classification. Where does that leave Diogenes (J43b)? He, unlike Themistius, does refer explicitly to Aristotle. Given that this is a genuine fragment of Aristotle, it is an easy assumption that the point being made in it is the one about generic classification familiar from Poetics 1 . Yet 'between poetry and prose' is not a particularly good formulation of Aristotle's argument in Poetics 1, that imitations in verse and imitations in prose are subsets of a single, as yet nameless art. ${ }^{23}$ Moreover, Aristotle in Poetics 1 does not talk about Plato in particular, but about Socratic dialogues in general: by contrast, the Aristotelian observation which Diogenes reports is specifically about Plato. We know that Aristotle had views on the use of poetic elements in prose style (Rhet. 3.1, 1404a20-40), and I see no reason why $O n$ Poets should not have included discussion of stylistic differences between poetry and prose. So $\mathbf{J} \mathbf{4 3 \mathbf { b }}$ is a genuine fragment of Aristotle, and Janko may well be right in attributing it to On Poets; but by hastily assimilating it to a familiar passage from Poetics, he has misidentified its original context. If that construction of the facts is correct, we need not assume that Aristotle took so favourable a view of the poetic elements in Plato's prose style as Themistius does: he insists on the distinction between prose and poetic diction (Rhet. 3.1, 1404a38-9). ${ }^{24}$ That hypothesis is, of course, speculative; but, in accordance with the need for caution when dealing with fragments, it has the merit of not asserting itself with unwarranted confidence.

There is one further piece of evidence that might be seen as supporting the argument for Themistius' dependence on Aristotle's generic classification in J43a. Janko points out that psilometria occurs elsewhere only in the Poetics, and comments (508):

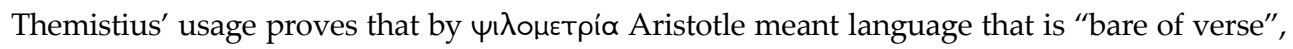

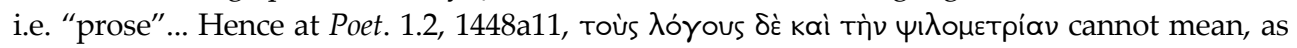
everyone has thought, "prose and unaccompanied verse", but rather "prose literature that lacks verse-form", with epexegetic kaí.
}

This argument is seriously flawed. Themistius' usage proves what he meant when he used the word: what Aristotle meant should be judged, not from someone else's use of the word, but from the context in which Aristotle himself used it. I find Janko's reinterpretation of that context entirely unconvincing. The structure of Poetics 2, 1448a7-18 is based on a four-part sequence:

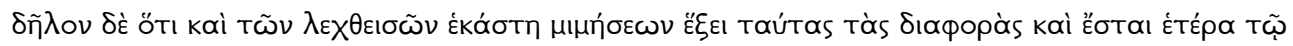

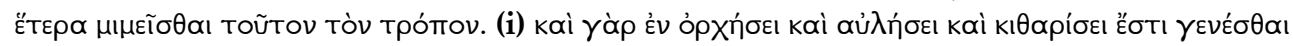

\footnotetext{
22 For the metaphor compare Long. Subl. 7.2, 36.1, 36.3.

23 At one point Janko says that Aristotle 'argues' that non-verse mimesis is poetry (217). If this were true, then 'between' would be even less appropriate.

24 Dionysius of Halicarnassus includes Aristotle among the critics of Plato's style (ad Pomp. 1.16, 226.10-15 Usener-Radermacher). Aristotle is sharply critical of Plato's 'empty verbiage and poetic metaphors' at Met. 1.9, 991a20-2 (= 13.5, 1079b24-6; cf. An.Po. 2.13, 97b37-9). The assessment of Plato at Pol. 2.6, 1265a10-13 is more subtly ambivalent: Halliwell 2006 provides an acute analysis.
} 


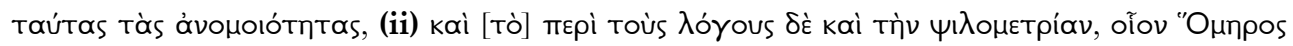

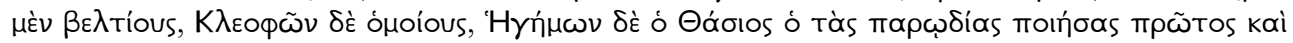

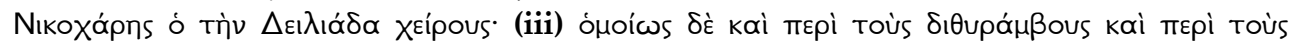

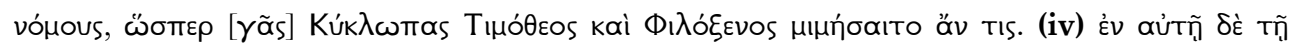

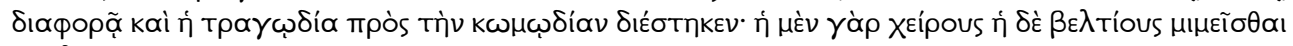

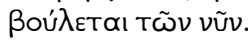

It is clear that each of the kinds of imitation mentioned above will also exhibit these differences, and will be distinguished by the imitation of distinct objects in this way. For these dissimilarities are possible (i) both in dance and in music for pipe or lyre, (ii) and also in connection with language and unaccompanied verse: for example, Homer imitates better people; Cleophon people similar to us; Hegemon of Thasos, who invented parodies, or Nicochares, the author of the Deiliad, worse people; (iii) similarly also in connection with dithyrambs and nomes one could imitate as Timotheus and Philoxenus did the Cyclopes; (iv) and the very same difference distinguishes tragedy and comedy from each other: for the latter aims to imitate people worse than our contemporaries, the former better.

This sequence recapitulates the arts mentioned in 1, 1447a13-16, ${ }^{25}$ dividing them according to the permutations of rhythm, language and melody established in chapter 1: (i) = rhythm, with or without melody $(\sim 1447 \mathrm{a} 23-8)$; (ii) = rhythm and logos $(\sim 1447 \mathrm{a} 28$ b13); (iii) = rhythm, language and melody used in combination throughout $(\sim$ 1447b24-6); and (iv) = rhythm, language and melody distributed in separate parts ( 1447b26-8). Janko posits an 'unnoticed parenthesis' (508) in 1448a9-11, embracing

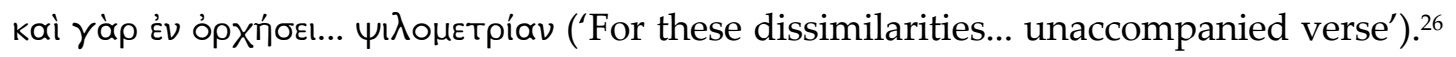
But this parenthesis destroys the internal logic of the passage, and in doing so also disrupts its cohesion with chapter 1 . I therefore conclude that Themistius used the word in a different sense from Aristotle. That is not to say that he misunderstood Aristotle's usage. Themistius was under no obligation to conform to Aristotle's usage when crafting his own prose. He could achieve a pleasingly erudite effect by deploying an item of vocabulary which he had met in the Poetics, and could do so with little risk of confusing his readers, since he was using it in a contextually transparent sense. ${ }^{27}$ Themistius was a sophisticated literary artist, pursuing his own agenda, and it does him an injustice to treat his text as a passive conduit for the evidence for Aristotle's lost works that we would so much like to have.

\section{The evidence of Philodemus}

Let us turn now to the fragments from Philodemus. The condition of the papyri from which traces of Philodemus' text have to be recovered poses special difficulties. The reconstruction of the text itself from these incomplete and indistinct remains is also fraught with problems. I am not the only reader of the first volume of Janko's edition to have been struck by the peculiarity of some of the Greek attributed to Philodemus; the translations, too, are often ones that I would have struggled to get out of the Greek.

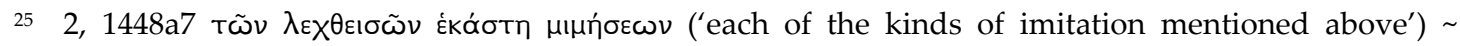

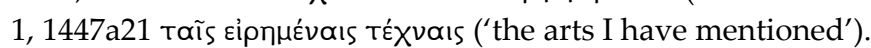

26 In 1448a11, тoùs $\lambda$ óyous signals the progression from purely instrumental music to imitation in language, while $\psi \mathbf{\imath} \lambda$ онєтрía indicates that we are not yet concerned with language with melodic accompa-

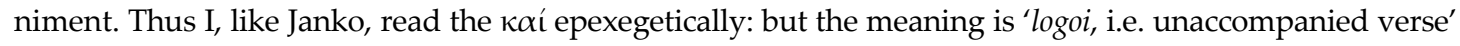
(not 'prose literature that lacks verse-form').

27 Synesius was sufficiently impressed to reproduce the effect in Dion 18, if Bernays' plausible emenda-

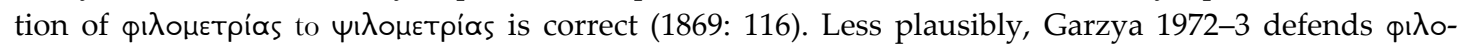
цєтрías in Synesius, emending Themistius to match.
} 
That does not prove that Janko's reconstruction is wrong. If we knew Aristotle's Metaphysics or Plotinus' Enneads only from papyri excavated at Herculaneum, our reconstructions would be wrong if they were not linguistically challenging. ${ }^{28}$ On the other hand, it is doubtful whether we would have succeeded in reconstructing the peculiarities of Aristotle's or Plotinus' lost texts correctly had we been reliant on Herculaneum papyri.

These considerations provide grounds for approaching the reconstructed evidence of Philodemus with caution, but not for ignoring it. At On Poems 4, col. 106.8-9 (= J3)

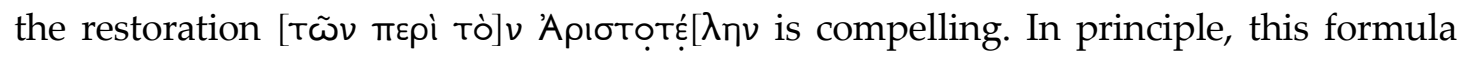
would be consistent with a collective reference to Aristotle and his followers; but reading it (in accordance with a familiar idiom) as a periphrastic singular reference to Aristotle is, as Janko argues (220-1), more consistent with the manner of the following polemic. Janko also makes a good case against the Poetics as the Aristotelian source (330-62); the inference that the source is On Poets is therefore attractive. On the other hand, we know that Philodemus made use of doxographic aids when compiling On Poems; $; 2$ so the possibility that he is engaging with On Poets at second hand needs to be considered, ${ }^{30}$ as do his own polemical habits. There are therefore still questions that need to be posed about the value of this evidence and about its responsible use.

First, let us consider an example of the work of restoration that needs to be performed on the evidence of Philodemus' text in order to produce something that looks like Aristotle. Philodemus has just introduced the topic of characters; this is how Janko reconstructs the text that follows (On Poems 4, col. 109.17-21):

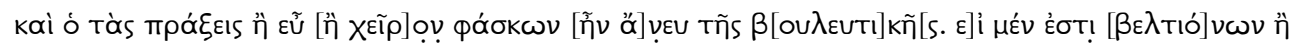
$\kappa \alpha \theta^{\prime} \dot{\eta} \mu \tilde{\alpha}[s$ กं $\pi \rho \tilde{\alpha} \xi 15 . .$.

And the one who said "the actions either well or worse" was without deliberative capacity. If it is "of those better than us" ... (followed by c. 48 missing words) ${ }^{31}$

From this he reconstructs a fragment of Aristotle (J8):

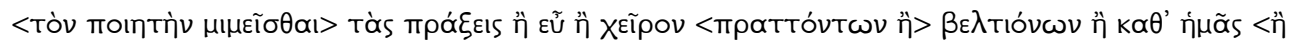

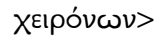

$<$ The poet imitates $>$ the actions either well or worse <of agents either $>$ better than us <or worse $>32$

28 Longinus, a native speaker of Greek and a philosophically educated contemporary of Plotinus, complained to Porphyry that copies of some of Plotinus' works that had been sent to him were full of errors-yet Porphyry assures us that they were accurate copies (Porph. VP 19.21-3, 20.5-9).

29 See Janko 228-9. Janko 391 acknowledges that Philodemus' knowledge of other Aristotelian dialogues may have been direct or indirect.

30 There are some items of vocabulary not otherwise attested for Aristotle: noınuatıkós (elsewhere only

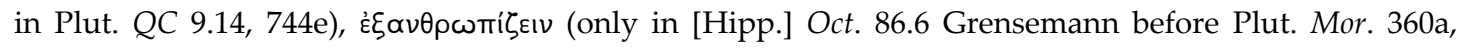
$582 \mathrm{~d})$.

31 Janko 277 translates: "The person who claimed that "(the poet represents) the actions either well or badly" was incautious. If on the one hand the action belongs to "those who are better than we are"...' The phrase in parenthesis is a clarification, not a supplement: that is, it does not translate words which Janko believes were present in Philodemus' text (see next note).

32 Janko 417 translates: ' (... that the poet represents) either well or badly the actions of (characters) who are (either) better than we are (or worse).' In Aristotelian fragments, Janko places words which he believes were omitted by Philodemus in round brackets (undefined in his sigla but explained on 330; cf. 403). I will follow the standard convention, and use angled brackets to mark editorial supplements to a text as transmitted. 
Did Aristotle write those words in On Poets? Possibly. Is the text of Philodemus sufficient evidence that he did? No: it provides Janko with a peg for a conjectural reconstruction that is made possible by his knowledge of the Poetics. There are three methodological corollaries. First, where we do not have independent knowledge of the kind of thing that an author is likely to have written, Philodemus may not provide adequate evidence for what the author actually wrote. Secondly, to the extent that such conjectural reconstructions depend on our prior knowledge they cannot securely add to our knowledge of Aristotle's views. Thirdly, convergence between On Poets as reconstructed by Janko and the Poetics is not evidence that Aristotle's views remained constant: it is an inevitable result of Janko's method, since consistency with the Poetics is a criterion for his identification and reconstruction of fragments of On Poets. Consider J12: faced with a statement that seems to conflict with what Aristotle says in the Poetics, Janko suggests that it 'belongs to a speaker in the dialogue who opposes Aristotle's view, unless the philosopher himself argued in utramque partem' (337). So, when Janko later concludes that 'Aristotle does not seem to have changed his views of poetry' between On Poets and the Poetics (389), we should reflect that evidence for a change in Aristotle's views could not be brought to light by a procedure which eliminates apparent inconsistencies.

It is, nevertheless, true that $O n$ Poets was a dialogue. It is therefore probable that not everything said in On Poets was a statement of Aristotle's own views. We need not, for example, feel under any obligation to conclude that Aristotle himself was of the considered opinion that Homer's father was 'one of the spirits that dance with the Muses' (J65a). As Janko says of such anecdotes, 'since they were within a dialogue, Aristotle did not have to vouch for them himself' (317). But this does not apply only to anecdotes: one of the formal characteristics of Aristotelian dialogues accepted by Janko is that 'everything was discussed from opposing points of view' (324, my emphasis).33 This, too, has methodological consequences. On the one hand, arguments against the attribution of a fragment to On Poets on grounds of inconsistency with other evidence for Aristotle's views are not conclusive. For example, if we had positive reason to believe that Janko's J34, J35 and J36c were all fragments of Aristotle's On Poets, that work's dialogue form would provide a possible explanation of the apparently discrepant opinions about the origins of tragedy which they contain. Janko's harmonising explanation of the apparent discrepancies between these fragments (365-71) would still be superfluous. ${ }^{34}$ On the other hand, the dialogue form gives us an additional reason for being cautious in reconstructing Aristotle's views from citations of On Poets, in Philodemus or elsewhere.

The case of $\mathbf{J 1 2}$ provides a good illustration of the importance and the difficulty of deciding whether or not a view expressed within the dialogue is Aristotle's own view. I am not convinced that Janko is right to say that the fragment is inconsistent with what Aristotle says in the Poetics. The statement (extracted from Philodemus) that 'some have tried to thoroughly humanize ( $\dot{\xi} \xi \nu \theta \rho \omega \pi i \zeta \varepsilon \varepsilon)$ tragedy' is not in conflict with Aristotle's idea that tragedy represents 'characters superior to ordinary human beings' (Janko 337: cf. Poet. 2, 1448a1-18), any more than the statement that some poets

\footnotetext{
33 Citing Laurenti 1987: I.55-73.

34 That is not, of course, enough to confirm Janko's speculative attributions: we still have no positive reason to believe that these are all fragments of On Poets.
} 
distort the continuity of their plots (Poet. 9, 1451b35-2a1) is in conflict with the idea that tragedy is an imitation of a complete action (Poet. 6, 1449b24-5; 7, 1450b21-34). A normative theory (for example, that stealing is wrong) is not contradicted by a report of deviations from the norm (for example, that some people steal). Either way, this example has important implications for Philodemus' reliability as a source. If I am right, Philodemus' charge of inconsistency (On Poems 4, col. 111.10-112.3) depends on treating a practice reported by Aristotle as a practice endorsed by Aristotle. If Janko is right, Philodemus' charge of inconsistency depends on treating a view expressed in Aristotle as a view expressed by Aristotle. On both readings, Philodemus' argument is worthless. Though such crude misrepresentation would not be out of keeping with his style of polemic, ${ }^{35}$ we should acknowledge that the confusion might not be Philodemus' fault: if he was not working directly from On Poets, he ran the risk of being misled by his predecessors' attempts to summarise Aristotle's views, as well as by his own polemical zeal. Wherever the fault lies, there are limits to the confidence that can be placed in Philodemus' reports of Aristotle; and even when we think we can make sense of his rebuttals, there are severe limits to the confidence with which we can recover from them what Aristotle meant by the words to which Philodemus is responding.

\section{The evidence for katharsis}

Potentially the most important of the fragments from Philodemus are those that relate to katharsis, a concept which readers of Aristotle and of Greek tragedy continue to find irresistibly fascinating and frustratingly impenetrable. Janko says that the fragments of Philodemus 'confirm the recent consensus, derived above all from Pol. 8, that Aristotelian catharsis was a process in which the emotional effect of watching a mimesis habituates us to approach more closely to the mean in terms of our reactions to real-life events, and hence helps us to attain the virtues of character' (374). I do not think that that such a consensus exists (except in the tautological sense that there is a consensus among those who accept that interpretation). But to the extent that such a consensus does exist, Philodemus does not confirm it. As we shall see, Janko himself identifies one aspect of the view of katharsis which he finds in Philodemus as a surprise. But there are also surprising and problematic elements which Janko seems not to have noticed.

There are three relevant fragments, all from On Poems book 5. One, which merely

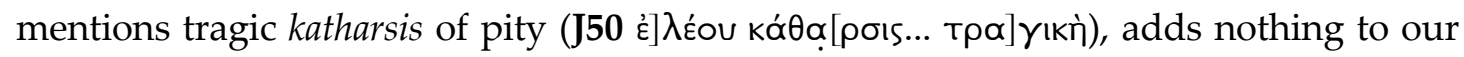
knowledge. Another (J46) has more substantial content, indicating that katharsis is beneficial with regards to virtue:

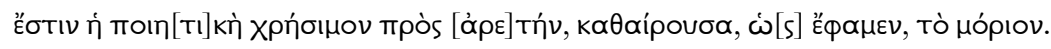

Poetry is useful for virtue, purifying [kathairousa], as we said, the part.

That is the somewhat cryptic text of Philodemus. In the fragment of Aristotle as Janko reconstructs it, Philodemus' text is supplemented with what he surmises (after Nardelli) are the words of Aristotle which Philodemus omitted:

\footnotetext{
35 Janko sometimes dignifies Philodemus' point-scoring distortions with the title reductio ad absurdum (e.g. 274 n.6; 297 n.8). That is a technical term, and should be used with more precision.
} 


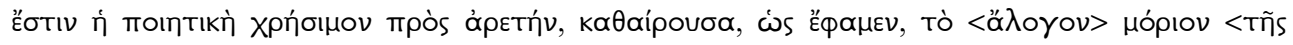
భuXñs>.

Poetry is useful for virtue, purifying [kathairousa], as we said, the $<$ non-rational $>$ part $<$ of the soul $>.36$

The surprise comes in J47:

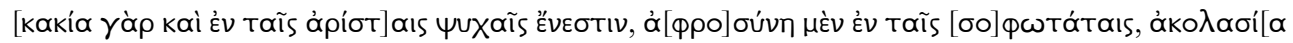

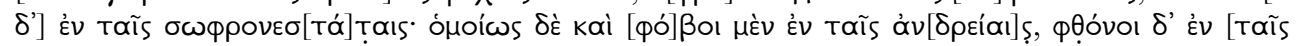
$\mu] \varepsilon \gamma \propto \lambda$ 워́징.

For there is vice even in the best souls: (i) folly in the wisest, and (ii) self-indulgence in the most temperate; similarly there are also (iii) fears in brave souls, and (iv) jealousies in magnanimous ones.

In view of what follows, the supplement in the initial lacuna ('For there is vice even in the best...') is plausible. But two problems are worth noting. First, wisdom is an intellectual virtue, not a virtue of character. The extension of katharsis to intellectual virtue is not part of any recent consensus: it is, in Janko's words, 'a real surprise' (513). Various questions spring to mind. Can an intellectual defect be repaired by the mechanism of emotional habituation, or must its katharsis involve some different process? If so, what process? Does an intellectual virtue have the same structure as a virtue of character? In other words, is wisdom a mean? If it is, between what excess and defect does wisdom lie? ${ }^{37}$ Can the katharsis of an intellectual defect be reconciled with Janko's text of J46? Janko does not explain how katharsis of an intellectual deficiency can be achieved by operating on the non-rational part of the soul. A second problem in J47 is that the catalogue of vices in the best souls is strikingly anomalous. In (i) an intellectual virtue (sophia, theoretical wisdom) is paired with a deviation from a different intellectual virtue. ${ }^{38}$ In (ii), a virtue of character is paired with a deviation from the same character virtue. In (iii), a virtue of character is paired with one of that same virtue's affective prerequisites. ${ }^{39}$ In (iv) a virtue of character is paired with an affective disposition which, though especially incongruent with that virtue, is always deviant. ${ }^{40}$ On the

\footnotetext{
36 See n.32 above. Janko's translation: 'The (art of) poetry is something useful with a view to virtue, purifying, as we said, the (irrational) part (of the soul).'

37 Janko's answer seems to be that folly is an excess: 'folly is juxtaposed with cowardice, intemperance, and irritability in a similar list of excesses at 7.7, 1149a5-6' (514). But he has misread the text: Aristotle says that any of these things in an extreme form is either bestial or pathological.

38 As Janko puts it, 'the greatest scientific or artistic genius may still be a dunce at taking practical decisions' (513). One would expect practical folly (á $\varphi \rho \circ \sigma u ́ v \eta)$ to be contrasted with practical wisdom (фpóvnoıs: EE 7.2, 1236a5; 8.1, 1246b5-7, 18; Rhet. 1.11, 1371a13; 3.9, 1410a7-8). It is, in fact, possible that Aristotle did think of practical wisdom (phronessis) as a mean at some point in his career (considered, but not confidently affirmed, in Pearson 2007; see also, briefly, Reeve 2012: 129). This possibility is of no help to Janko, however, since he identifies sophia as theoretical or technical wisdom, in accordance with Aristotle's normal usage (for the latter possibility see NE 6.7, 1141a9-12). In Poet. 18, 1456a22-3, where Sisyphus is described as sophos but wicked, the word may refer to the morally neutral capacity for prac-

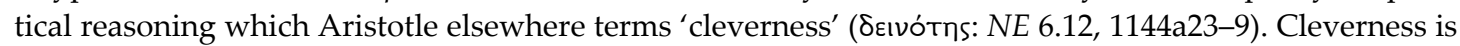
necessary, but not sufficient, for practical wisdom. But Philodemus specifies 'the best souls': and a soul that has cleverness but not practical wisdom would not qualify.

39 There must be fears in the courageous soul, since courage is a mean with regard to fear and confidence (NE 3.6, 1115a6-7; cf. 3.7, 1115b7-20, 24-8). So in this case, the evidence for vice in the best souls is that they have something that they must have if they are to be courageous (and not reckless).

40 For the deviance of phthonos see NE 2.6, 1107a8-14; 2.7, 1108a35-b5; cf. EE 2.3, 1221a38-9; Top. 2.2, 109b37-8; Rhet. 2.11, 1388a34-5. It receives no special mention in Aristotle's discussion of megalopsukhia
} 
face of it, this seems desperately incoherent. I am not so rash as to assert dogmatically that these problems are insoluble, or that it is impossible to extract a coherent and Aristotelian account of katharsis from the fragments that give rise to them; but I have not yet succeeded in doing so. Nor has Janko: he shows no sign of having noticed that the problems exist, and makes no attempt to address them. ${ }^{41}$

One reason why $\mathbf{J 4 7}$ is a surprise is that it is entirely isolated. None of the other texts that have been proposed as sources of indirect evidence for Aristotle's theory of poetic katharsis contains any hint of its promoting intellectual virtue: they all speak of an effect on the emotions. We ought, then, at least to consider the possibility that Philodemus' evidence on this point is erroneous. Alternatively, if Philodemus' evidence is right, it follows that the rest of the indirect evidence for Aristotle's theory is positively misleading in its incompleteness. Both horns of this dilemma have discouraging implications for the project of using indirect evidence to recover Aristotle's theory. But there is a third possibility, still more discouraging: for one could doubt the reliability of Philodemus' evidence without being convinced that the rest of the indirect evidence is reliable. The only responsible way to proceed is to consider in each case whether or not there are sufficient grounds for treating a given passage as indirect evidence for Aristotle's thinking on katharsis.

Since there were other theories of katharsis, the fact that a passage is concerned with tragic and comic katharsis is not sufficient on its own to warrant our treating it as evidence for Aristotle's theory. Here, at least, Janko and I agree. He once included a passage from Olympiodorus' commentary on Plato's Gorgias (33.3, 172.6-23 Westerink) among the testimonia to Aristotle's theory, but has since changed his mind: the passage is omitted from this edition on the grounds that it probably derives from a similar theory of Theophrastus' (406). ${ }^{42}$ In a series of passages in his commentary on the First Alcibiades, Olympiodorus distinguishes various conceptions of katharsis, one of which is associated with Aristotle by name (6.10-12), though also later described as 'Peripatetic or Stoic' (54.15-55.14) and 'Aristotelian' (146.2-4). ${ }^{43}$ These passages do appear in Janko's collection, but only as a spurious fragment (†J75). His conclusion that Olympiodorus does not provide us with reliable evidence for Aristotle's theory is, in my judgement, correct. We agree, therefore, that reference to katharsis is not sufficient to warrant a passage being treated as evidence for Aristotle's theory. That is true even when Aristotle is named by the source of the putative fragment; a fortiori it will be true when he is not named.

(NE 4.3; EE 3.5); however, it is associated with mikropsukhia (Rhet. 2.10, 1387b34-5) and servility (Pol. $4.11,1295 \mathrm{~b} 21-3)$.

41 Nor does he give any adequate explanation when he extends katharsis from the correction of moral and intellectual errors in the audience to the correction of the errors of poets and of people in the poems (514-5, on J48 and J49). I have failed to make any sense of this at all.

42 Included in Janko 1987: 60 (cf. 1984: 147-8); retracted in Janko 2009.

43 'Peripatetic' does not refer specifically to Aristotle, and 'Aristotelian' need not (see e.g. Olympiod. in Cat. 48.37 Busse; in Mete. 27.22-3 Stüve; Proclus Tim. 1.262.5 Kroll; Philop. in DA 597.21, 28, 39 Hayduck). The element of this theory which Olympiodorus specifically attributes to Aristotle (6.9-11) is combating thumos with epithumia and vice versa, which is not found in any extant work of Aristotle (the parallel as 54.17-55.1 is printed, without independent attestation, as Chrysippus SVF 3.489); this idea is explained as healing by opposites $(6.11$; cf. $6.9 ; 54.17-18)$, which can be found in Aristotle, though not in connection with katharsis (NE 2.3, 1104b16-18; EE 2.1, 1220a34-7). 
Iamblichus, too, was familiar with at least one account of katharsis other than Aristotle's: in On the Mysteries 3.9 he mentions a theory that aulos music can have therapeutic effects on emotions and on bodily states; Iamblichus' denial that this should be described as katharsis indicates that it had been so described. Some have treated this passage as an Aristotelian fragment (F81c Rose; F6c Laurenti); Janko is right not to do so-indeed, he does not even include it in his list of omissions. ${ }^{44}$ What, then, is the evidence for Aristotle's anonymous presence in On the Mysteries 1.11 (J55, mentioned briefly in $\S 1$ above)? Janko claims that 'although Iamblichus does not name Aristotle, his concepts and wording are so similar that dependence on Aristotle, whether direct or indirect, is generally accepted' (519-20), and draws attention to the 'typically Aristotelian' antithesis between dunamis and energeia (520; cf. 1987: 186). The cogency of this evidence is easily tested. If the presence of this antithesis is to count as evidence that the passage derives from Aristotle, then the antithesis should be absent from passages in Iamblichus that are not derived from Aristotle. In On the Mysteries alone (and without including technical uses of the cognate verbs) there are approximately 180 and 80 occurrences of dunamis and energeia respectively, and they are juxtaposed as closely as they are in the passage under discussion in at least 15 other passages. These terms are therefore not evidence that the passage is derived from Aristotle: they are part of Iamblichus' own technical vocabulary, ${ }^{45}$ and he was perfectly capable of deploying them if he needed to summarise a theory of katharsis in his own words.

Moreover, one detail in this passage counts against its having preserved Aristotle's own wording: the potentials of human passions are to be brought to activation to a

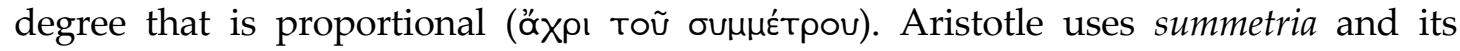
cognates freely. He routinely uses it in connection with physical health; and he does so in ethical contexts where he is using physical health as an analogy for virtue (NE 2.2, 1104a14-19; 10.3, 1173a23-8). Yet he never applies this terminology to emotionsthough the idea that emotions should be proportionate to their object is, of course, fundamental to his ethics. I do not think his avoidance of summetria in this context is coincidental. His regular form of expression, that emotions should be felt as they ought, in response to the things they ought, etc (e.g. NE 4.5, 1126b5-6), is clearer, more flexible in its capacity to express all the various dimensions in which emotions may be appropriate, and also (perhaps) less liable to be misunderstood as meaning 'not very much' ${ }^{46}$

44 The combination of psychological and physical healing points to Theophrastus (F726 Fortenbaugh);

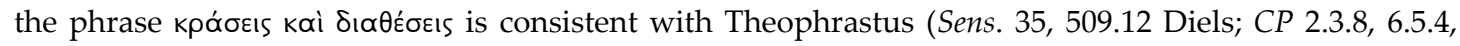
6.5.6), though not exclusive to him (Plut. Mor. 383b; 432d, 438c; 496a; 918d-e; Simpl. in DA 19.34 Hayduck).

45 See Steel 1978: 53-61; Shaw 1995: 34 n.28, 72-3, 78-9 and index ss.vv. Iamblichus is not alone: for Plotinus see Sleeman and Pollet 1980: 268-76, 374-83.

46 The Magna Moralia (which I take not to be by Aristotle) speaks of summetria between reason and emotion $(2.7,1206 \mathrm{~b} 9-11)$. The term is applied directly to emotions by later Peripatetics (Asp. in NE 1.5, 42.22, 44.18-19 Heylbut; Alex. Aphr. in Top. 99.10-11, 19 Wallies; [Alex. Aphr.] Eth. Probl. 146.23, 149.31150.3, etc Bruns) and Platonists (e.g. Plut. Mor. 443c-d; Max. Tyr. Or. 27, 3c; Plot. 6.8.5.28-30); Olympiodorus uses it in the accounts of Peripatetic-Stoic or Aristotelian katharsis that we have already seen are not Aristotle's (in Alc. 54.22, 146.4). Comparing Proclus in Remp. 1.82.5-7 Kroll with Rep. 2, 377e-8e will provide one example of the tendency to introduce the term summetria into reports of texts in which it did not appear. The use of the term in connection with katharsis was no doubt particularly encouraged by Pl. Soph. 227c-8d. As Janko notes, the Tractatus Coislinianus also has this usage in its definitions of tragedy ('tragedy... wants to have a summetria of fear') and comedy ('summetria wants to be of fear in tragedies, and of the laughable in comedies'). The status of the Tractatus as evidence for Aristotle is, 
Olympiodorus is not the only late Platonist to mention Aristotle in connection with katharsis: Proclus does so, too, though he does not mention Aristotle alone. In his commentary on the Republic $(1.49 .17-20$ Kroll $=$ J56) Proclus speaks of the objection to Plato's rejection of tragedy and comedy based on the thesis that a moderate satisfaction of the emotions will make them educable. He continues:

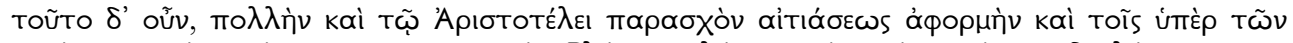

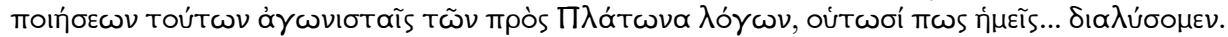

This, then, which provided Aristotle with ample opportunity for criticism, and the combatants on behalf of these kinds of poetry for their arguments against Plato, we shall solve... more or less as follows.

That is my translation; others have understood the Greek in the same, or a similar, way. ${ }^{47}$ But Janko translates the passage differently (459):

It was this that gave Aristotle, and the defenders of these (kinds of) poetry in his dialogue against Plato, most of the grounds for their accusation (against him). We shall refute this (objection)... as follows.

This translation is crucial for Janko's claim that 'Proclus... makes clear that he is citing the De poetis..., and proves that Aristotle and the characters in the dialogue responded explicitly to Plato's challenge' (520). ${ }^{48}$ But it is not tenable. As in a passage from Themistius discussed earlier, Janko offers 'dialogue' as a translation of logos-or, more precisely and even less plausibly, of logoi. Yet On Poets was hardly a 'dialogue against Plato', though it may well have included arguments (logoi) against Plato. More importantly, it is hard to see any reason why Proclus should have thought it worth giving separate mentions to Aristotle and other characters in the dialogue if they all shared Aristotle's critical stance towards Plato's views on poetry. ${ }^{49}$ (That is not like distinguishing, for example, the views of Socrates and Callicles in Gorgias.) It is much easier to see why Proclus would record, with disapproval, the fact that others (who would include Theophrastus) had jumped on Aristotle's anti-Platonic bandwagon. Since Proclus presents himself as responding to a tradition of responses to Plato that, though it originated with Aristotle, was not limited to him, we have no right to be confident that his summary carefully distinguishes the specifics of Aristotle's theory from later variations. That is, for our purposes, inconvenient. But Proclus, like Themistius, was not

however, itself disputed, and this use of summetria is one of the reasons for treating it with caution (as already noted by Barnes 1985: 106).

47 1857: 165 (= 1880: 47): 'Diesen Punkt nun, welcher dem Aristoteles vielen Anlass zu Vorwürfen und den Verfechtern jener Poesien zu Entgegnungen gegen Platon gegeben hat...' ('It was this that provided most of the grounds both to Aristotle for accusation and to the defenders of these kinds of poetry for their arguments against Plato': Janko 459 n.1). Bernays' version is accepted by Vahlen 1874: 296. Festugière 1970: I 67 understands the passage in the same way: 'Ce deuxième problème donc, qui a fourni à Aristote une ample occasion d'attaque, et aux défenseurs de ces genres poétiques prétexte à leurs écrits contre Platon...'. Compare (with a different, and in my view less satisfactory, rendering of

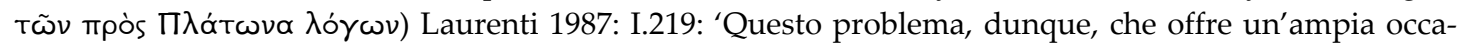
sione di critica e ad Aristotele e a quanti difendono tali generi di poesia contro gli scritti di Platone...'; Flashar, in Flashar, Dubielzig and Breitenberger 2006: 79: 'Das hat nun auch dem Aristoteles einen nicht geringen Anlass für seine Kritik gegeben und allen, die für diese Dichtungen eingetreten sind gegen die Worte Platons.'

48 Cf. Janko 1987: 186 ('provides a clear statement that he is citing the On Poets, and that Aristotle and the characters in the dialogue are responding to Plato's challenge'). Janko is here following Rostagni 1955: I.287-8.

49 As already noted by Laurenti 1987: I.263-4, in response to Rostagni. 
writing to serve as convenient repository of evidence for Aristotle; we must respect his agenda.

We have, then, no alternative: we must fall back on the direct evidence for Aristotle's theory of musical and poetic katharsis (Poet. 6, 1449b27-8; Pol. 8.6 1341a21-4; 8.7, 1341b32-2a18). Readers of the Poetics are acutely aware that its brief allusion to katharsis is not supplemented by any explanation. Most scholars turn to the discussion of musical katharsis in Politics 8.7 (J54) in the hope of finding clues to the explanation that is missing from the extant text of the Poetics; yet in the Politics Aristotle refers us to a work on poetics for a 'clearer' account (1341b38-40). ${ }^{50}$ His admission that the discussion in Politics 8 is an outline, lacking in explicitness, is discouraging. Nevertheless, the discussion in the Politics has significant advantages over all indirect sources. We know that Aristotle is expounding his own theory of katharsis; we can be confident that he did not misunderstand or misrepresent his theory; and the cross-reference gives us some assurance that the theory of musical katharsis has some relevant connection with the theory of poetic katharsis that is missing from the Poetics.

How close that connection is may depend on the scope of Aristotle's discussion of music in Politics 8. If mousike is used in a narrow sense, approximating to 'music' in modern usage, then this discussion of musical katharsis might stand at some distance from the lost discussion of poetic katharsis. Janko, however, maintains that Aristotle's usage in Politics 8 is broad: 'Movoikń not only means what we now call music, but includes the words, and therefore comprises poetry and song as well' (375, cf. 516: 'Movбiкń comprises song and poetry also'). Elsewhere he has claimed that 'everyone' used mousike in this broad sense 'down to Philodemus' De musica'. ${ }^{51}$ If this means that the word was always available for use in the broad sense, it is unobjectionable, but insufficient to determine the sense of the word in any given context. But if it means that the word was only used in the broad sense, and never referred to song and/or instrumental music as distinct from non-melodic poetry, it is false: in Poet. 26, 1462a14-16, mousike is something which tragedy has and epic does not; and that can only be song as distinct from non-melodic poetry. The sense in which Aristotle uses the term in Politics 8 is therefore an open question.

Janko believes that the question can be settled on internal evidence: 'Aristotle de-

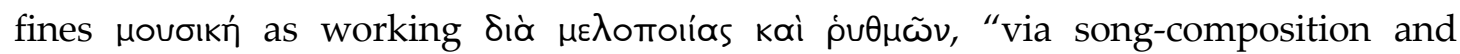
rhythms" (Pol. 8.7, 1341b24)' (375 n.1). This argument turns, obviously, on the claim that " $\mu \varepsilon \dot{\lambda} \lambda \eta$ are "songs", not "tunes"' (517). The translation is doubly anomalous. First,

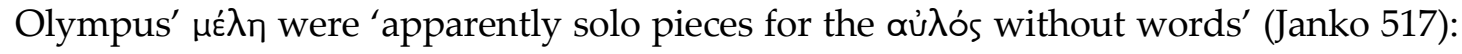
such purely instrumental compositions are not 'songs' in normal English usage. Secondly, Janko classifies epics and tragedies as $\mu \varepsilon^{\prime} \lambda$ : these, too are not 'songs' in normal English usage. More importantly, epics and tragedies are not $\mu \dot{\varepsilon} \lambda \eta$ in Aristotle's usage, either. Tragedies use $\mu \dot{\varepsilon} \lambda$ os in certain parts (Poet. 1, 1447b24-8; cf. 6, 1449b28-31)

\footnotetext{
50 Janko does not interpret this as a cross-reference to On Poets: he takes it as a reference to passages in the lost part of the Poetics, of which (more controversially) he believes the Tractatus Coislinianus preserves an epitome (518, citing Janko 1984: 136-51, 211-2: see n.46 above). J53 and J54 are therefore 'fragments' of On Poets only in an exceptionally attenuated sense: they are indirect evidence for what Aristotle said in the Poetics about a topic that was also discussed in On Poets.

51 Janko 2009: 270: 'This is supported by the fact that Theophrastus had a theory of catharsis that ap-

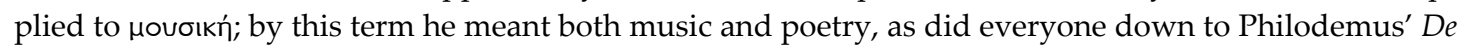
musica.'
} 
and therefore include $\mu \varepsilon \dot{\lambda} \eta$. It does not follow that they are $\mu \varepsilon \dot{\varepsilon} \eta \eta$. $\mu \varepsilon \lambda \circ \pi$ oría is not coextensive with the composition of tragedy, and is far from being its most important component $(6,1449 \mathrm{~b} 31-50 \mathrm{~b} 20)$; and it is primarily through the imitation of actions that tragedy evokes pity and fear and thus effects katharsis $(6,1449 \mathrm{~b} 27-8$, with e.g. 9, 1452a1-3; 14, 14531b1-14), not through the songs.

Janko may object that the reference to pity and fear in Pol. 8.7, 1342a7 (J54.2) 'proves that "songs relating to action" includes tragedy, which represents actions that arouse these emotions in particular' (519). But that does not help. To show that a tragedy is a song relating to action, it is not enough to show that it relates to action or that it arouses certain emotions: one must also show that it is a song. Nor does the fact that tragedy and epic represent character and action combine with the fact that 'rhythms and $\mu \varepsilon \dot{\varepsilon} \lambda \eta^{\prime}$ are associated with character and action (J53.3 = Pol. 8.5, 1340a14-23) to 'confirm' that ' $\mu \varepsilon \dot{\varepsilon} \lambda \eta$ are "songs", not "tunes"' (517). To show that $\mu \varepsilon^{\prime} \lambda \eta$ are not tunes, it is not enough to show that $\mu \varepsilon \dot{\varepsilon} \lambda \eta$ and songs can represent character and action: one must also show that tunes cannot do so-for if they can, the association of $\mu \varepsilon^{\prime} \lambda \eta$ with character and action is consistent with $\mu \varepsilon^{\prime} \lambda \eta$ being tunes. In what follows, Aristotle treats $\mu \varepsilon^{\prime} \lambda \eta$ and rhythms alike as representative of character $(\mathbf{J} 53.4-5=$ Pol. 8.5, 1340a38b10). This pairing of rhythms and $\mu \varepsilon \dot{e} \lambda \eta$ occurs four times in Politics 8 . Translating the phrase as 'rhythms and songs' awkwardly yokes songs with one structural component of songs. It makes better sense if the phrase designates the two dimensions in which songs and instrumental compositions are patterned, i.e. rhythm and melody. It is then equivalent to the phrase ' $\alpha$ puovía and rhythms', which occurs four times in Politics 8. 52 This interpretation is more consonant than Janko's with the dominant emphases of Aristotle's discussion of musical education, which seeks to determine which instruments children should learn to play at school, and which harmoniai and rhythms are educationally appropriate.

If music is not the same as poetry, there is an element of uncertainty about the identity of musical and poetic katharsis. Yet the cross-reference indicates some significant connection. The question, then, is whether the account of musical katharsis that emerges from the discussion in the Politics can be transferred to poetry. If the transfer is possible (perhaps with some degree of modification), then we would have an account of poetic katharsis that could be accepted as Aristotle's with some degree of confidence. The problem, obviously, is that we must first extract an account of musical katharsis from the Politics. The history of scholarship gives no grounds for optimism; but nor, perhaps, need we despair. In addition to the general advantages of direct over indirect evidence mentioned above, the direct evidence in this instance provides us with some resources. To attempt a full interpretation would exceed the remit of the present paper. ${ }^{53}$ But it is worth considering what can be concluded about the nature of Aristotle's response to Plato's critique of drama and Homeric epic.

In Republic 10, Plato excludes these kinds of poetry because they stimulate intense emotion. He maintains (i) that they are harmful, because they make us prone to inap-

52 Rhythm and melos: 8.5, 1340a13, 19; 8.6, 1341a1, 14. Rhythm and harmonia: 8.5, 1340a40-b10; 1340b1718; 8.7, 1341b19, 20-21. Cf. Poet. 6, 1449b29, where I agree with Janko (332 n.3) that the epexegetic kai

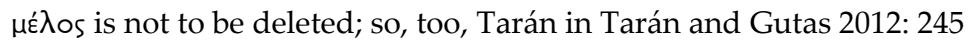

53 I have in the past tried to maintain an agnostic position on the nature of musical and tragic katharsis (most recently in Heath 2013: 93-4). My current research project will force me, in due course, to commit myself. See further Heath (in preparation). 
propriate emotion in real life (605c-6d); and (ii) that an argument in their defence would need to show that they are beneficial (607d6-9). If we set aside the libertarian response that harmfulness does not warrant legislative control (a view that Aristotle could not accept), any rebuttal will need to maintain that such poetry is not harmfuli.e. to deny (i). But two different strategies then become available: the first would maintain that such poetry is not only harmless but also beneficial; the second would maintain that harmlessness is sufficient defence, denying (ii) as well as (i). Which strategy does Aristotle adopt?

Here is a key passage (Pol. 8.7, 1342a4-18):

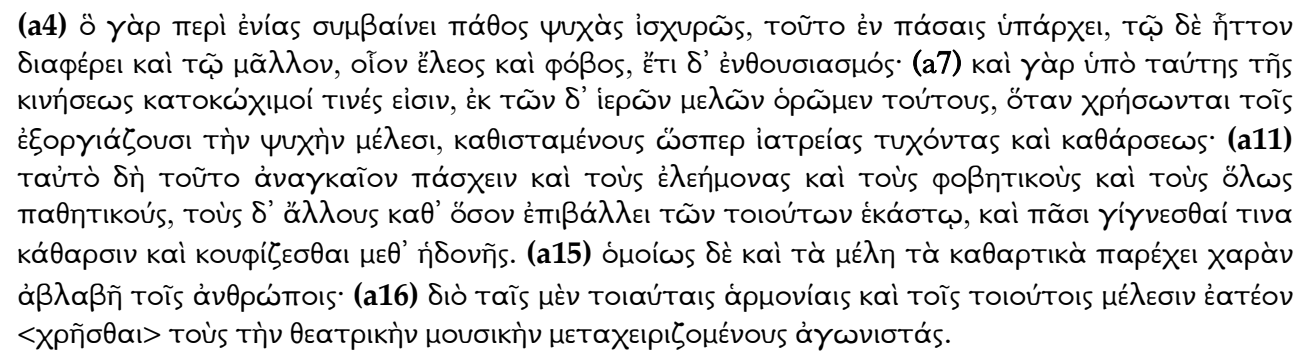

(a4) For the affect that occurs in some souls strongly exists in all, but in different degrees: e.g. pity and fear. And also enthusiasm. (a7) For some are possessed by this disturbance, too, and we see that, under the influence of the sacred melodies, whenever they employ the melodies that excite extreme frenzy in the soul, they are restored, as if having undergone medical treatment [iatreia] and katharsis. (a11) The very same thing, necessarily, is experienced by those prone to pity or to fear or, in general, to any affect, and by others to the extent that each is susceptible to such things; and for all there comes about a certain katharsis and alleviation [kouphizesthai] with pleasure. (a15) In the same way, kathartic melodies, too, provide harmless pleasure to human beings. (a16) This is why the use of such harmoniai and such melodies should be allowed to competitors taking part in public musical performances.

Aristotle is here setting out an argument. That argument is prompted by, and aims to justify, the statement that immediately precedes: practical and enthusiastic harmoniai, though not appropriate for children's education, are appropriate for listening to others performing (a3-4). The argument's success is marked by an explicit statement of the conclusion reached (a16-18); careful attention to the argument's structure should reveal what Aristotle sees as sufficient grounds for reaching that conclusion. The argument proceeds directly from asserting that kathartic melodies provide harmless pleasure (a15-16) to the conclusion which licenses the use of such melodies in public performance (a16-18). The implication is that Aristotle regards harmlessness as sufficient defence-in other words, that he is following the second of the two strategies mentioned above.

Denying that such music needs to be beneficial does not commit Aristotle to denying that such music ever is beneficial; and it is clear that Aristotle believes that music can be beneficial. The effect of the 'sacred melodies' on those who are pathologically prone

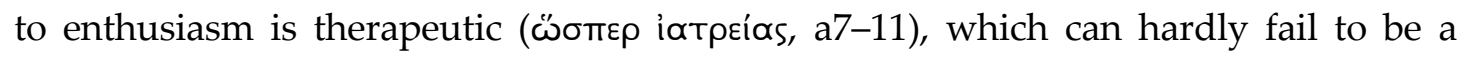
benefit. Why, then, does Aristotle shift to the weaker claim that kathartic music is harmless immediately before drawing his conclusion? Here, too, attention to the structure of the argument is important. As the argument progresses its scope extends beyond those pathologically prone to enthusiasm to include people across the whole range of emotional susceptibility; in the course of that progression, Aristotle moves from 'as it were medical treatment and katharsis' (a10-11) to 'katharsis and alleviation 


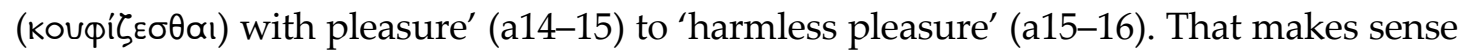
if he thinks that the benefit in the pathological cases cannot be generalised to all cases: what can be generalised is the combination of harmlessness and pleasure; and that, in Aristotle's view, is sufficient. Another passage in Politics suggests that Aristotle took the same view in the case of poetry: he permits adults to attend performances of comedy, not because they will benefit from it, but because their education immunises them against the harm that comedy can do to young people $(7.17,1336 \mathrm{~b} 20-3)$.

Though I have spoken of Aristotle 'responding' to Plato's critique, that may not be the most helpful way to describe what is happening in the passage on musical katharsis. Compare Aristotle's comment on the representation of gods in poetry (Poet. 25, 1460b35-1a1), which is a 'response' to Plato only in the sense that it manifests Aristotle's disagreement with Republic 2; it is not a response to Plato in the sense of arguing that he was wrong. Similarly, the discussion of katharsis manifests Aristotle's disagreement with an argument about music analogous to the argument about poetry in Republic 10, but it does not engage directly with that argument: when it asserts that such music is harmless, it implicitly refuses the demand that a defence should demonstrate benefits, but does so without argument. Aristotle is not willing to allow Plato to set the rules for the debate (why should he?), but instead presents conclusions which he has reached from premises based on his own (not Plato's) understanding of ethics and human psychology.

Those premises are presupposed, and not articulated in the passage itself. They are not drawn to the reader's attention. Readers in whose thoughts Plato's critique is prominent will understandably find it natural to interpret Aristotle on the assumption that Plato's challenge was being met on the terms that Plato had laid down: that is, they will assume that he must have been trying to show that the emotional stimulus is beneficial. ${ }^{54}$ Modern readers who make that false assumption will find confirmation of their understanding of Aristotle in the indirect evidence provided by ancient readers who made the same false assumption. The resulting consensus will be a consensus in error.

\section{Conclusion}

Working with fragments is a hazardous enterprise. Excessive caution condemns us to remain in ignorance, which is a bad thing; but lack of restraint may betray us into believing falsehoods, which is worse. The history of scholarship is littered with the corpses of source-critical hypotheses which, after becoming the basis for far-reaching conjectural constructs and being widely accepted as securely established, succumbed to the sceptical scrutiny that exposed their inadequate foundations. With hindsight it is easy to see in such cases how over-confident acceptance of insecure conjectures put research onto a false trail. Yet in a discipline in which certainty is hard to come by, total abstinence from conjecture is necessarily stultifying. The balance between excessive

\footnotetext{
54 Janko's misreading (520: 'Ford... denies that Aristotle responded to Plato's attack on poetry') of Ford 2004: 334 ('My reading of Politics 8 will disappoint those who want to see Aristotle taking up Plato's challenge in the Republic to show in prose is not only a source of pleasure but also of benefit to political communities and human life $(607 \mathrm{~d})$... To respond that tragedy is "educational" is not to defeat Plato but to capitulate to him') illustrates the power of that assumption: it transforms Ford's denial that Aristotle responded on Plato's own terms into a denial that he responded at all.
} 
caution and over-confidence is hard to strike. At both the individual and the collective levels, the progress of research depends on a dialectic between boldness and caution. ${ }^{55}$

To disapprove on principle of Janko's bold endeavour would therefore be absurd. ${ }^{56}$ If there is evidence that will help us to understand Aristotle, we need to know about it; and we will never find it if no one is prepared to look for it. But, as Janko says, it is crucial that we should be 'prepared to formulate and test such hypotheses' (362, my emphasis). In this paper, I have put some of hypotheses advanced in Janko's edition of the fragments of On Poets to the test, ${ }^{57}$ and have found them compromised by multiple failures of methodology and judgement. But there is also a deeper failure. Janko does not recognise the fragility of his conjectures, and fails to alert users of his work to the need for caution. Indeed, his hypotheses are consistently delivered with the utmost confidence and a tendency to overstatement: 'confirms', 'proves' and 'certainly' are favoured words. This edition is therefore likely to give its users, especially users who are not experts on Aristotle or the later texts which are adduced as indirect evidence, a dangerously misleading impression of the solidity of its conclusions. ${ }^{58}$

\author{
Malcolm Heath \\ Professor of Greek Language and Literature \\ University of Leeds \\ E-mail: M.F.Heath@leeds.ac.uk
}

\footnotetext{
55 Heath 2002: 107.

56 Janko 362: 'With the odds stacked against those who would argue for authenticity in such cases, it is not to be wondered at if scholars prefer not to take the risk, and even disapprove on principle of those who do.' But Janko does not identify any scholar who has expressed disapproval of the endeavour on principle, and I can think of none.

57 Other examples could be added. I cannot resist giving passing mention to the pages (327-8) in which Janko, reluctant to believe that Aristotle could have endorsed an allegorical interpretation of Homer (F175 Rose), hypothesises that the Homeric Questions were in dialogue form (those who share Janko's doubts about F175 would do better to consider the possibility that our sources record a solution mentioned but not endorsed by Aristotle), and then founds a conjecture about the speakers in this hypothetical dialogue on the work of that supremely inventive fantasist, Ptolemy son of Hephaestion, also known as Ptolemy Chennus (on whom see Cameron 2004: 134-63).

58 Research for this paper was undertaken during my tenure of a Leverhulme Major Research Fellowship (F10099B). The Leverhulme Trust's support is gratefully acknowledged.
} 


\section{Appendix 1}

See n.10 above for an explanation of this Appendix.

\section{John the Deacon 149.6-150.10 Rabe}

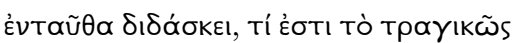

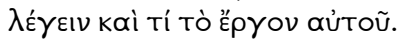

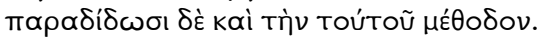

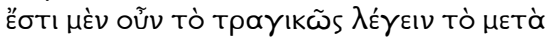

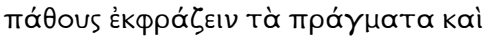

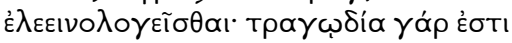

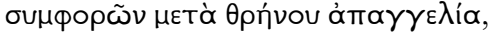

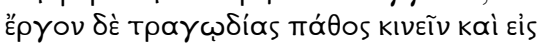

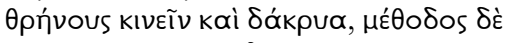

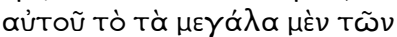

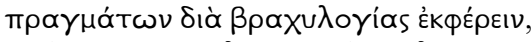

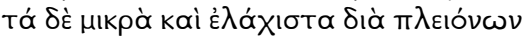
á $\pi \alpha \gamma \gamma \varepsilon \dot{\lambda} \lambda \varepsilon \varepsilon \nu$.

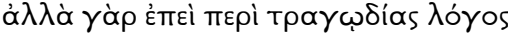

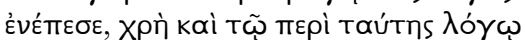

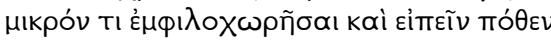

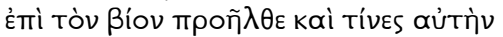

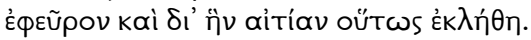

\section{Gregory of Corinth, RG 7.1328.8-9.1}

Walz

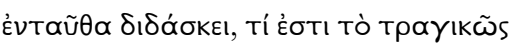

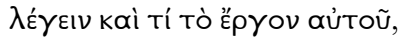

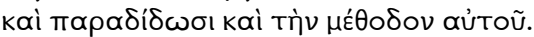

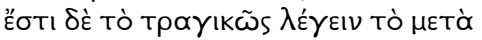

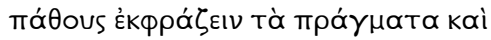

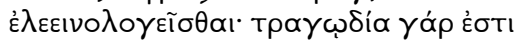

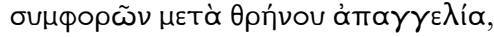

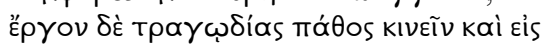

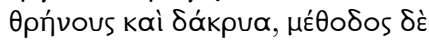

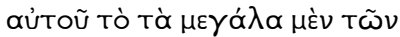

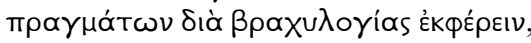

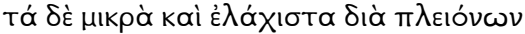

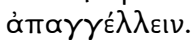

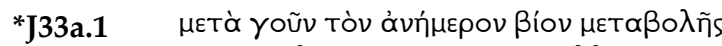

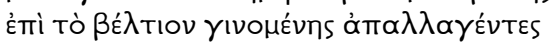

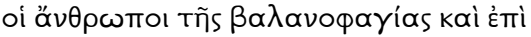

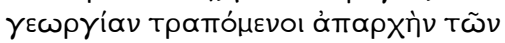

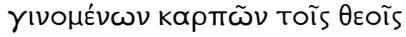

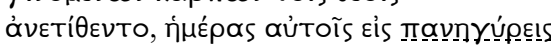

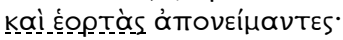

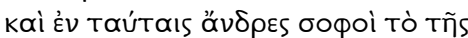

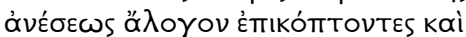

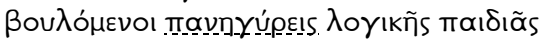
$\mu \varepsilon T \varepsilon ́ \chi \varepsilon I V$

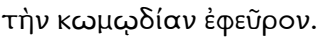

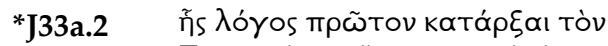

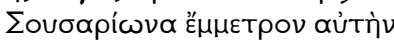

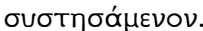

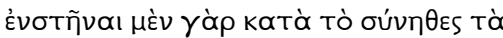

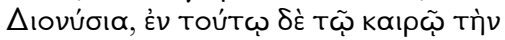

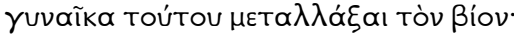

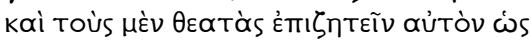

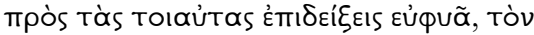

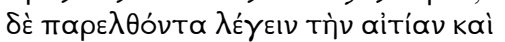

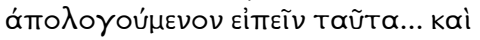

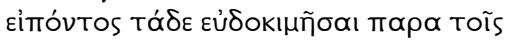
àkoúovol.

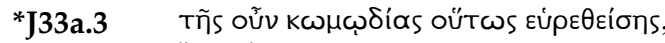
iv $u$ a $\mu$ ì

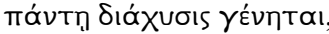

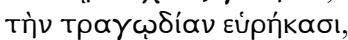

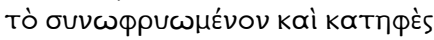

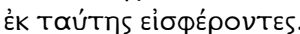

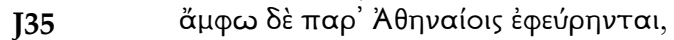

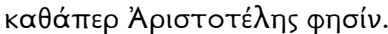

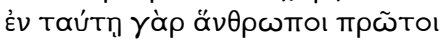




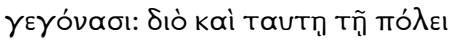

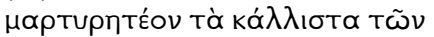

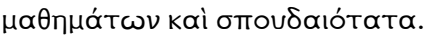

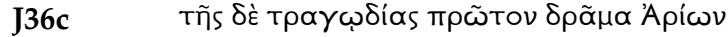

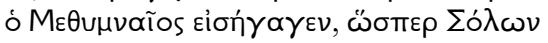

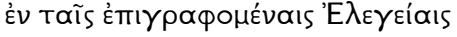
$\varepsilon \dot{\delta} \delta \dot{\delta} \propto \xi \varepsilon$.

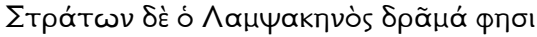

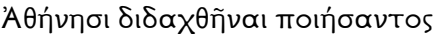

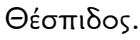




\section{Appendix 2: Concordance}

* = fragment doubtfully attributed to On Poets (Janko 2011), or doubtfully attributed to Aristotle (Rose). J32 is marked as doubtful in Janko's text, but not in his commentary or concordance. In Janko 1987 asterisks mark fragments conjecturally attributed to On Poets: since this is a different criterion, I have omitted them here to avoid confusion.

$\dagger=$ spurious fragment (Janko 2011).

italicised fragment numbers $=$ fragments which other editors (Rose, Gigon) do not assign to On Poets. I have supplied some numbers from Gigon's 'Fragmente ohne Buchangabe' omitted from Janko's concordance.

Under status, I have indicated which texts I would include if I were compiling a collection of sources; since I am not compiling such a collection, the judgements should be regarded as very provisional.

$\mathrm{P}=\mathrm{a}$ text that I would include as a source for On Poets (in some cases hesitantly).

$\mathrm{A}=\mathrm{a}$ text that I would include as a source for Aristotle, but could not assign to On Poets with any confidence.

In some cases I would include only a limited part of the text printed by Janko (see the discussions of J35 and J38 above). Inclusion does not imply endorsement: texts in which Aristotle is explicitly named have been included even if I believe that their evidence is unreliable (e.g. +J75); this includes cases where a named reference to Aristotle is complicated by mention of others (e.g. J56).

\begin{tabular}{|c|c|c|c|c|c|c|}
\hline \multicolumn{7}{|l|}{ Janko } \\
\hline 2011 & 1987 & Rose $^{3}$ & Gigon & Laurenti & Source & Status \\
\hline${ }^{*} 1-{ }^{*} 2$ & 3 & & & & Philodemus & \\
\hline $3-10$ & 3 & & & & Philodemus & $\mathrm{P}$ \\
\hline *11 & & & & & Themistius Or. 34.11 & \\
\hline $12-30$ & 3 & & & & Philodemus & $\mathrm{P}$ \\
\hline $31 \mathrm{a}$ & 11 & $* 676$ & 937 & $4 a$ & sch. Cicero & $\mathrm{P} ?$ \\
\hline $31 b$ & & & & & Didymus & \\
\hline $31 c$ & & & & & GL 6.107.10-12 Keil & \\
\hline- & 12 & & & & anon. POxy. 2389 & \\
\hline *32 & 16 & & & & sch. Dionysius Thrax & $\mathrm{A}$ \\
\hline *33a & & & & & John Diaconus & \\
\hline *33b & & & & & Gregory of Corinth & \\
\hline 34 & $14 \mathrm{~b}$ & & & & Themistius 27 (337ab) & \\
\hline 35 & $14 a$ & & & & John Diaconus & A (part) \\
\hline $36 a$ & 13 & $* 677 a$ & 919 & $4 \mathrm{~b}$ & Proclus Chrestomathy & $\mathrm{P} ?$ \\
\hline $36 b$ & & & & & sch. Plato & \\
\hline $36 c$ & & & & & John Diaconus & \\
\hline $36 \mathrm{~d}$ & & $* 677 b$ & & & Suda (s.v. Arion) & \\
\hline$* 37 \mathbf{a}$ & & & & & Pausanias (Atticist) & \\
\hline$* 37 b-c$ & & & & & Zenobius (paroemiast) & \\
\hline$* 37 \mathrm{~d}$ & & & & & anon. PBerol. 9571 & \\
\hline 38 & $15 a$ & & & $4 \mathrm{c}$ & Themistius 26 (316ad) & $\begin{array}{l}\mathrm{P} ? \\
\text { (part) }\end{array}$ \\
\hline *39-*40 & & & & & Ar. Byz. (?), POxy. 3219 & \\
\hline 41 & & & & & & \\
\hline
\end{tabular}




\begin{tabular}{|c|c|c|c|c|c|c|}
\hline 42 & $15 b$ & & & & D.L. 3.56 & \\
\hline $43 a$ & & & & & Themistius 26 (316d-9a) & \\
\hline $43 b$ & 2 & 73 & 862 & 5 & D.L. 3.37 & $\mathrm{P}$ \\
\hline 44a & $1 \mathrm{a}$ & $72 b$ & 15 & $3 b$ & Athenaeus & $\mathrm{P}$ \\
\hline $44 \mathrm{~b}$ & & & & & Eustathius & \\
\hline $44 \mathrm{c}$ & $1 \mathrm{~b}$ & & & & Ar. Byz. (?), POxy. 3219 & $\mathrm{P}$ \\
\hline $44 d$ & & & & & Heracleodorus & \\
\hline $44 \mathrm{e}$ & $1 \mathrm{c}$ & $72 \mathrm{a}$ & 14 & $3 a$ & D.L. 3.48 & $\mathrm{P}$ \\
\hline $45-52 b$ & 4 & & & & Philodemus & \\
\hline *52c & & & & & John Philoponus & $\mathrm{A}$ \\
\hline $53-54$ & $\mathrm{~A}$ & & & & Aristotle $(\mathrm{Pol})$. & \\
\hline 55 & $\mathrm{~B}$ & $81 b$ & 893 & $6 b$ & Iamblichus Myst. 1.11 & \\
\hline- & & $81 c$ & & $6 c$ & Iamblichus Myst. 3.9 & \\
\hline 56 & $\mathrm{C}$ & $81 a$ & 921 & $6 a$ & Proclus in Remp. & A et al. \\
\hline 57 & $\mathrm{E}$ & & & $\mathrm{T} 1$ & Aristotle (Poet.) & $\mathrm{P}$ \\
\hline 58 & 7 & 74 & 16 & 7 & Macrobius & $\mathrm{P}$ \\
\hline 59 & \multirow[t]{3}{*}{5} & & & & \multirow[t]{3}{*}{ Aristocles } & \\
\hline$* 60-* 61$ & & & & & & \\
\hline $62-63$ & & & & & & $\mathrm{P} ?$ \\
\hline$* 64$ & 6 & & & & Philodemus & \\
\hline $65 a$ & 9 & $76 a$ & 20.1 & $9 a$ & [Plut.] De Hom. & $\mathrm{P}$ \\
\hline $65 b$ & & $76 \mathrm{e}$ & 20.4 & & anon. Vit. Hom. & $\mathrm{P}$ \\
\hline $65 c$ & & $76 \mathrm{~b}$ & 20.5 & $9 b$ & Gellius & $\mathrm{P}$ \\
\hline $65 d$ & & $76 c$ & 20.2 & & [Plut.] De Hom. & $\mathrm{P}$ \\
\hline $65 \mathrm{e}$ & & $76 \mathrm{~d}$ & 20.3 & & anon. Vit. Hom. & $\mathrm{P}$ \\
\hline $66 a$ & 8 & $75 a$ & 21.1 & 8 & D.L. 2.46 & $\mathrm{P}$ \\
\hline $66 \mathrm{~b}$ & & $75 b$ & 21,2 & & D.L. $8.48-9$ & \\
\hline $66 c$ & & & & & Tzetzes & \\
\hline *67a & & & & & Aelian & \\
\hline$* 67 b$ & & & & & Eustathius & \\
\hline *68 & & $7 b$ & 27 & & Cicero & $\mathrm{A}$ \\
\hline *69 & & & & & anon. POxy. 2506 & $\mathrm{~A}$ \\
\hline *70 & & & & & anon. POxy. 2734 & A \\
\hline$* 71$ & & 66 & 865 & $2 c$ & D.L. 8.63 & A \\
\hline$* 72 a$ & & $71 \mathrm{a}$ & 18 & $2 a$ & D.L. $8.51-2$ & $\mathrm{~A}$ \\
\hline$* 72 b$ & & $71 \mathrm{~b}$ & 19 & $2 b$ & D.L. 8.74 & $\mathrm{~A}$ \\
\hline 73 & 10 & 70 & 17 & 1 & D.L. 8.57 & $\mathrm{P}$ \\
\hline *74 & & & & & Plutarch & $\mathrm{A}$ \\
\hline+75 & $\mathrm{Di}$ & & & & Olympiodorus in Alc. & A et al. \\
\hline- & Dii & & & & Olympiodorus in Gorg. & \\
\hline- & & 77 & 22 & 10 & Bekker Anecdota 1.101 & \\
\hline
\end{tabular}

\section{REFERENCES}

Barnes, J. (1985) 'Editor's notes.' - Phronesis 30, 99-110.

Bernays, J. (1869) Die Heraklitischen Briefe. Ein Beitrag zur philosophischen und religionsgeschichtlichen Litteratur. Berlin: Hertz.

Bernays, J. (1857) Grundzüge der verlorenen Abhandlung des Aristoteles über Wirkung der Tragödie. Breslau: Trewendt. Reprinted in Zwei Abhandlungen über die aristotelische

Theorie des Drama (1880). Berlin: Hertz.

Bremer, J. (1988) Review of Janko 1984. - Mnemosyne 41, 166-70. 
Cambiano, G. (2002) 'Catastrofi naturali e storia umana in Platone e Aristotele.' - RSI $114,694-714$.

Cameron, A. (2004) Greek Mythography in the Roman World. New York: Oxford University Press.

Festugière, A. J. (1970) Proclus. Commentaire sur la République. Paris: Vrin.

Flashar, H.; Dubielzig, U.; Breitenberger, B. (2006) Aristoteles. Fragmente zu Philosophie, Rhetorik, Poetik, Dichtung. Darmstadt: Wissenschaftliche Buchgesellschaft.

Ford, A. (2004) 'Catharsis: the power of music in Aristotle's Politics.' - Murray, P.; Wilson, P. (eds.), Music and the Muses. Oxford: Oxford University Press, 309-36.

Fortenbaugh, W. W. (1987) Review of Janko 1984. - CP 82, 156-64.

Fortenbaugh, W. W. et al. (1992) Theophrastus of Eresus. Sources for his Life, Writings, Thought and Influence. Part I. Leiden: Brill.

Garzya, A. (1972-3) 'Varia philologica.' - Athina 73-74, 365-8; reprinted in Storia e interpretazione di testi bizantini: saggi e ricerche (London 1974), XX(ix).

Gigon, O. (1987) Aristotelis Opera III: Fragmenta. Berlin: de Gruyter.

Halliwell, S. (2006) 'An Aristotelian perspective on Plato's dialogues.' - Herrmann, F.-G. (ed.), New Essays on Plato. Language and Thought in Fourth-Century Greek Philosophy. Swansea: Classical Press of Wales, 189-211.

Heath, M. (2002) Interpreting Classical Texts. London: Duckworth.

Heath, M. (2013) Ancient Philosophical Poetics. Cambridge: Cambridge University Press.

Heath, M. (in preparation) Poetical Animals. Aristotle, Anthropology and Poetry

Janko, R. (1984) Aristotle on Comedy. Towards a Reconstruction of Poetics II. London: Duckworth.

Janko, R. (1987) Aristotle, Poetics. With the Tractatus Coislinianus, a Hypothetical Reconstruction of Poetics II, the Fragments of the On Poets. Indianapolis: Hackett.

Janko, R. (2000) Philodemus. On Poems Book I. Oxford: Oxford University Press.

Janko, R. (2009) 'A new comic fragment (Aristophanes?) on the effect of tragedy.' CQ 59, 270-1.

Janko, R. (2011) Philodemus. On Poems Books Three and Four. With the fragments of Aristotle On Poets. Oxford: Oxford University Press.

Laurenti, R. (1987) Aristotele. I frammenti dei dialoghi. Naples: Loffredo.

Pearson, G. (2007) 'Phronesis as a mean in the Eudemian Ethics.' - OSAP 32, 273-95.

Rabe, H. (1908a) 'Aus Rhetoren-Handschriften: 5. Des Diakonen und Logotheten Jo-

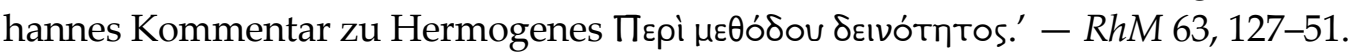

Rabe, H. (1908b) 'Aus Rhetoren-Handschriften: 6. Weitere Textquelle für Johannes Diaconus.' - RhM 63, 512-17.

Reeve, C. D. C. (2012) Action, Contemplation, and Happiness. An Essay on Aristotle. Cambridge MA: Harvard University Press.

Rose, V. (1886) Aristotelis qui ferebantur librorum fragmenta. Leipzig: Teubner.

Rostagni, A. (1955) Scritti Minori. Turin: Bottega d'Erasmo.

Schenkeveld, D. (1986) Review of Janko 1984. - Gnomon 58, 212-7.

Sedley, D. (2007) Creationism and its Critics in Antiquity. Berkeley: University of California Press.

Shaw, G. (1995) Theurgy and the Soul. The Neoplatonism of Iamblichus. University Park PA: Pennsylvania State University Press.

Sleeman, J. H.; Pollet, G. (1980) Lexicon Plotinianum. Leiden: Brill. 
Steel, C. (1978) The Changing Self. A study on the Soul in Later Neoplatonism: Iamblichus, Damascius and Priscianus. Brussels: Palais der Academiën.

Tarán, L.; Gutas, D. (2012) Aristotle's Poetics. Editio Maior of the Greek Text with Historical Introductions and Philological Commentaries. Leiden: Brill.

Vahlen, J. (1874) 'Wo stand die verlorene Abhandlung des Aristoteles über Wirkung der Tragödie?' - SWAW 77, 293-8.

Verlinsky, A. L. (2006) 'The flood in Aristotle's «Meteorologica» (I. 14).' - Antike Naturwissenschaft und ihre Rezeption 16, 51-68.

Walsdorff, F. (1927) Die antiken Urteile über Platons Stil. Bonn: Scheur. 